\title{
Growth of Pepper under Different Concentration of the Solutions Used in the Hydroponic System
}

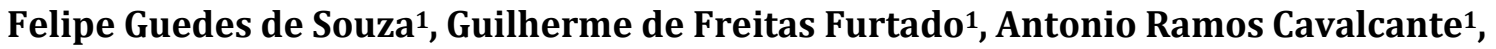 \\ Lucia Helena Garófalo Chaves ${ }^{*}{ }^{*}$, Josely Dantas Fernandes ${ }^{1}$, José Amilton Santos Júnior² \\ ${ }^{1}$ Department of Agricultural Engineering, Federal University of Campina Grande, Campina Grande, Brazil \\ ${ }^{2}$ Department of Agricultural Engineering, Federal Rural University of Pernambuco, Recife, Brazil \\ Email: felipeguedes.eng@gmail.com,gfreitasagro@gmail.com, antoniosoledade@gmail.com, ^lhgarofalo@hotmail.com, \\ joselysolo@yahoo.com.br, eng.amiltonjr@hotmail.com
}

How to cite this paper: de Souza, F.G., de Freitas Furtado, G., Cavalcante, A.R., Chaves, L.H.G., Fernandes, J.D. and Júnior, J.A.S. (2018) Growth of Pepper under Different Concentration of the Solutions Used in the Hydroponic System. Agricultural Sciences, 9, 925-935.

https://doi.org/10.4236/as.2018.98064

Received: July 20, 2018

Accepted: August 6, 2018

Published: August 9, 2018

Copyright $\odot 2018$ by authors and Scientific Research Publishing Inc. This work is licensed under the Creative Commons Attribution International License (CC BY 4.0).

http://creativecommons.org/licenses/by/4.0/

\begin{abstract}
Water availability is a fundamental condition for sustainable agriculture. However, a satisfactory water condition is not always possible in terms of quantity and quality in certain regions, such as the Brazilian semi-arid region. Thus, the purpose of this extremely important research was to evaluate the growth of cv. All Big with six combinations of wastewater plus saline (WW + $\mathrm{SW}$ ) and two nutrient solution percentages, in a low-cost hydroponic system. The experiment was carried out in a greenhouse at the Department of Agricultural Engineering at Federal University of Campina Grande. A completely randomized experimental design was used, with treatments arranged in a factorial scheme $(6 \times 2)$, with 5 replications, being the treatments composed by the combination of six proportions of wastewater with saline water (50\%/50\%; $60 \% / 40 \% ; 70 \% / 30 \% ; 80 \% / 20 \% ; 90 \% / 10 \% ; 100 \%$ of wastewater) and two nutrient solution concentration ( $80 \%$ and $100 \%)$, totalizing 60 experimental units. The biometric variables were analyzed at 55 and 96 days after sowing, namely: plant height (PH), stem diameter (SD), leaf number (LN) and leaf area (LA). The interaction between the concentration of the nutrient solution and the ratio of the saline water with wastewater was influenced in the behavior of peppers (cv. All Big) biometric variables. The nutrient solution prepared at $80 \%$ of its normal concentration had better performance in the development of plants when mixed with the proportions of water containing more wastewater. The proportion $30 \%$ saline water and $70 \%$ wastewater (30/70) with concentration of $80 \%$ of the nutrient solution obtained better satisfactory results in the studied biometric variables.
\end{abstract}




\section{Keywords}

Capsicum annuum L., Saline Water, Wastewater, Nutrient Solution

\section{Introduction}

Water availability is a fundamental condition for sustainable agriculture. However, a satisfactory water condition is not always possible in terms of quantity and quality in certain regions, such as the Brazilian semi-arid region, due to its rainfall index, high evapotranspiration rates and geological formation [1]. In this region, the use of inferior water quality (water with excess salts and/or waste water) for the irrigation of the crops has been used as a strategy to coexist with the scarcity of water resources. However, it is necessary to search for technologies that promote the rational use of these waters in plant production reducing negative environmental impacts. One of these technologies is the cultivation in the hydroponic system that according to [2] refers to an alternative technique of plant cultivation with balanced nutrient solution in the absence or presence of natural or artificial substrates.

However, according to [3] the use of conventional hydroponics has some disadvantages in small rural communities, such as the high initial cost, the risk of loss of the crop due to problems related to electric energy, the need for specialized manpower and the ongoing monitoring in response to the nutritional solution that requires special management care, as well as market issues, incompatible with family farming, vulnerability and the degree of decapitalization of family farmers.

In this sense, hydroponic systems with closed circulation can make possible the use of lower quality water, such as wastewater, because preventing the direct application of these waters to the soil avoids the direct contact of the man with these waters and promotes the use of nutritional support. However, even under hydroponic conditions, it cannot dispense techniques that mitigate the deleterious effects of excess salts on these waters, such as the mixing of the wastewater and/or saline water with rainwater [4].

The capsicum (Capsicum annuum L.), belonging to the Solanaceae family, is one of the five crops with the highest area under protected cultivation, both in Brazil and in several countries due to the great productivity and quality of the fruits [5]. However, in order to ensure these advantages, it is necessary to adapt the management to the protected environment, especially in relation to water supplementation, since the pepper is very demanding in water and is considered moderately sensitive to salinity.

In a protected environment, it is possible to produce pepper during the whole year. However, because hydroponics is a recent cultivation technique, there are few studies in the literature with pepper yields, as well as the effect of water quality and concentration of nutrient solution for more productive peppers. 
Furtado et al. [6] evaluating the growth of pepper in a hydroponic system under different levels of electrical conductivity of nutrient solution, observed that plant height, stem diameter and number of leaves decreased with the increase in saline concentration. Thus, the purpose of this research was to evaluate the growth of cv. All Big pepper under six combinations of wastewater plus saline water (WW + SW) and two nutrient solution percentages, in a low-cost hydroponic system.

\section{Material and Methods}

The experiment was carried out in a greenhouse from March to July 2017, at the Department of Agricultural Engineering at Federal University of Campina Grande, located in the municipality of Campina Grande, $\mathrm{PB}$, at the local geographic coordinates $7^{\circ} 15^{\prime} 18^{\prime \prime} \mathrm{S}, 35^{\circ} 52^{\prime} 28^{\prime \prime} \mathrm{W}$ and altitude of $550 \mathrm{~m}$.

A completely randomized experimental design was used, with treatments arranged in a factorial scheme $(6 \times 2)$, with 5 replications, being the treatments composed by the combination of six proportions of wastewater with saline water (50\%/50\%; 60\%/40\%; 70\%/30\%; $80 \% / 20 \% ; 90 \% 10 \% ; 100 \%$ of wastewater) and two nutrient solution concentration $(80 \%$ and $100 \%$ recommended by [7], totalizing 60 experimental units. In the preparation of 1000 liters of this nutrient solution the following salts were used with the respective amounts in grams: hydro special calcium nitrate $(750 \mathrm{~g})$; potassium nitrate $(500 \mathrm{~g})$; monoammonium phosphate (150 g); magnesium sulphate (400 g); conmicros $^{\star}(42.5 \mathrm{~g}){ }^{*}$ mixture of micronutrients for hydroponics).

The experimental units consisted of the low-cost hydroponic system module [8] being that this system consists of a $6 \times 1.40 \mathrm{~m}$ wooden support waterproofed with oil paint, projected with supporting capacity for 12 PVC tubes, leveled, with $6 \mathrm{~m}$ of length and $100 \mathrm{~mm}$ of diameter. The tubes were perforated with circular "cells" of $60 \mathrm{~mm}$ diameter, equidistantly spaced according to $0.20 \mathrm{~m}$, considering the central axis of each cell. Tube elbows with the same diameter were attached to the tubes and taps were installed in order to allow water outflow, as in an overflow pipe system, and maintain a constant water level of $4 \mathrm{~cm}$ along the tubes, for uniform distribution of solution to plants.

In the preparation of the treatments, saline water from a community water of Victoria Settlement $\left(7^{\circ} 20^{\prime} 47.49^{\prime \prime S}\right.$; $\left.36^{\circ} 2^{\prime} 28^{\prime \prime} \mathrm{W}\right)$ with the following characteristic: $\mathrm{pH}(8.24), \mathrm{ECw}\left(29.15 \mathrm{dS} \cdot \mathrm{m}^{-1}\right), \mathrm{K}\left(0.31 \mathrm{meq} \cdot \mathrm{L}^{-1}\right), \mathrm{Na}\left(239.13 \mathrm{meq} \cdot \mathrm{L}^{-1}\right)$, $\mathrm{Ca}\left(20.5 \mathrm{meq} \cdot \mathrm{L}^{-1}\right), \mathrm{Mg}\left(100 \mathrm{meq} \cdot \mathrm{L}^{-1}\right)$ and SAR of $30.81\left(\mathrm{mmol} \cdot \mathrm{L}^{-1}\right)^{0.5}$, was mixed with rain water in a proportion of $30 \mathrm{~L}$ : $100 \mathrm{~L}$ reaching the electrical conductivity around $3 \mathrm{dS} \cdot \mathrm{m}^{-1}$. The wastewater was obtained at the Experimental Station of the National Institute of Semiarid-INSA/MCTI, Campina Grande-PB, Brazil ( $7^{\circ} 16^{\prime} 41^{\prime \prime S}$; $35^{\circ} 57^{\prime} 59^{\prime \prime} \mathrm{W}$; $470 \mathrm{~m}$ ), with the following characteristic: $\mathrm{pH}$ (8.94), $\mathrm{EC}_{\mathrm{w}}\left(1.71 \mathrm{dS} \cdot \mathrm{m}^{-1}\right), \mathrm{K}\left(0.75 \mathrm{meq} \cdot \mathrm{L}^{-1}\right), \mathrm{Na}\left(6.52 \mathrm{meq} \cdot \mathrm{L}^{-1}\right), \mathrm{Ca}\left(0.78 \mathrm{meq} \cdot \mathrm{L}^{-1}\right), \mathrm{Mg}$ $\left(2.12 \mathrm{meq} \cdot \mathrm{L}^{-1}\right)$ and SAR of $5.41\left(\mathrm{mmol} \cdot \mathrm{L}^{-1}\right)^{0.5}$. Then, after the mixtures of these waters used to compose the treatments, they were combined with the nutrient solution [7] with two concentrations, $80 \%$ and $100 \%$. 
The sowing of the pepper (Capsicum annuum L.) All Big cultivar was in plastic cups of $200 \mathrm{~mL}$, perforated in the sides and bottom, which were filled with 10 $\mathrm{g}$ of substrate coconut fiber; the seedlings were irrigated daily, in the morning and in the afternoon, with rainwater up to 33 days after sowing (DAS). At 34 DAS, the germination cups, with seedlings + substrate were placed in the cells according to previously established treatments.

Although biometric variables were analyzed at 55, 68, 82 and 96 DAS, in this study, the data were only presented at 55 and 96 DAS, that is, the beginning and end dates of the pepper crop. Intermediate data were not presented because they are very similar to the others. The biometric variables analyzed were as follows: plant height (PH), stem diameter (SD), leaf number (LN) and leaf area (LA).

Plant height $(\mathrm{cm})$ was determined from the plant neck to the bifurcation of the last leaf; the SD $(\mathrm{mm})$ was measured in the lap of the plant at $0.02 \mathrm{~m}$ from the soil; and counting the number of leaves (units) were considered to be healthy, synthetically active, fully expanded with minimum length of the central rib of $3 \mathrm{~cm}$. The LA was measured by the non-destructive method, using the methodology proposed by [9] according to Equation (1).

$$
\mathrm{LA}=\left[(0.61906 * L * W)+\left(0.206 * L^{2}\right)-(0.5142 * L)\right]
$$

on what:

$$
\begin{aligned}
& \text { LA = leaf area }\left(\mathrm{cm}^{2}\right) ; \\
& L=\text { leaf length }(\mathrm{cm}) ; \\
& W=\text { leaf width }(\mathrm{cm}) .
\end{aligned}
$$

Data were analyzed using a statistical software SISVAR [10]. Analysis of variance (ANOVA) was conducted and significance of differences among treatment was tested using the " $F$ " test at a 0.05 and 0.01 probability level. In the cases of significance, interaction or main factors alone, a Tukey test analysis was performed for proportions between saline water and wastewater and Student's t-test for nutrient solution concentrations.

\section{Results and Discussion}

The interactions between the factors, the proportion of the water mixtures $(\mathrm{P})$ and the concentration (C) in the experimental units had a significant effect on all biometric variables, plant height, stem diameter, leaf number and leaf area at 55 and 96 DAS. The "P" factor did not affect the SD, LN and LA at 55 DAS and the "C" factor did not affected the PH at 96 DAS and the LN and LA at 55 DAS (Table 1).

According to the split of the interaction between the water ratios (SW/WW) and nutrient solution concentrations for plant height at 55 days after sowing, it can be observed in Figure 1 that the highest height was reached $7.03 \mathrm{~cm}$ using the proportion $30 \% / 70 \%$ of the SW and WW waters together with the concentration of $100 \%$ of nutrient solution. However, there was no significant difference in the height of the plants cultivated with the $50 \% / 50 \%$ and $100 \%$ of 


\section{DAS}

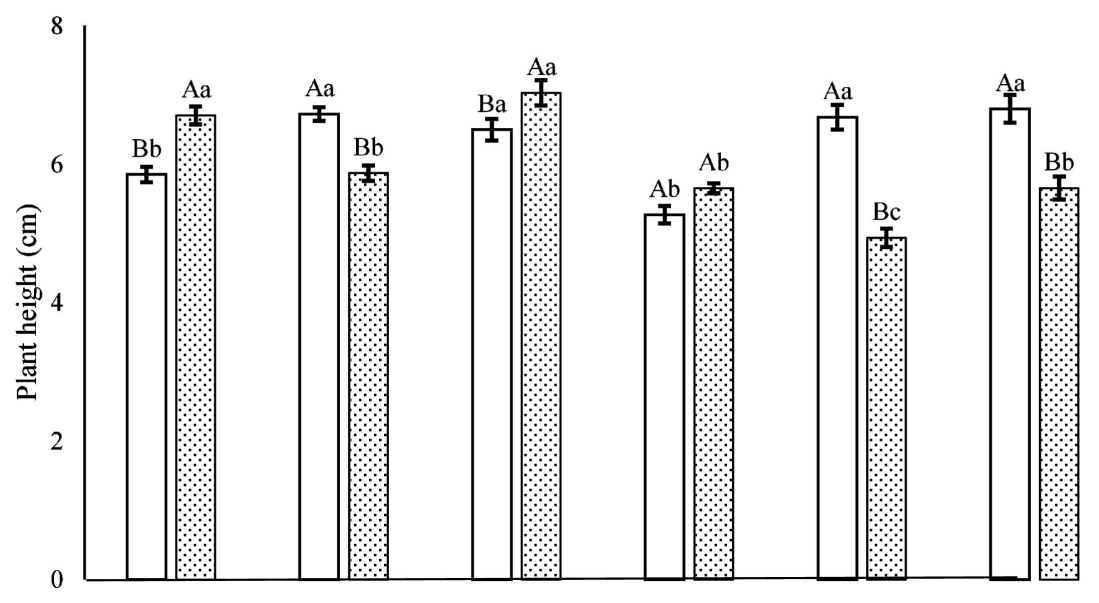

96 DAS

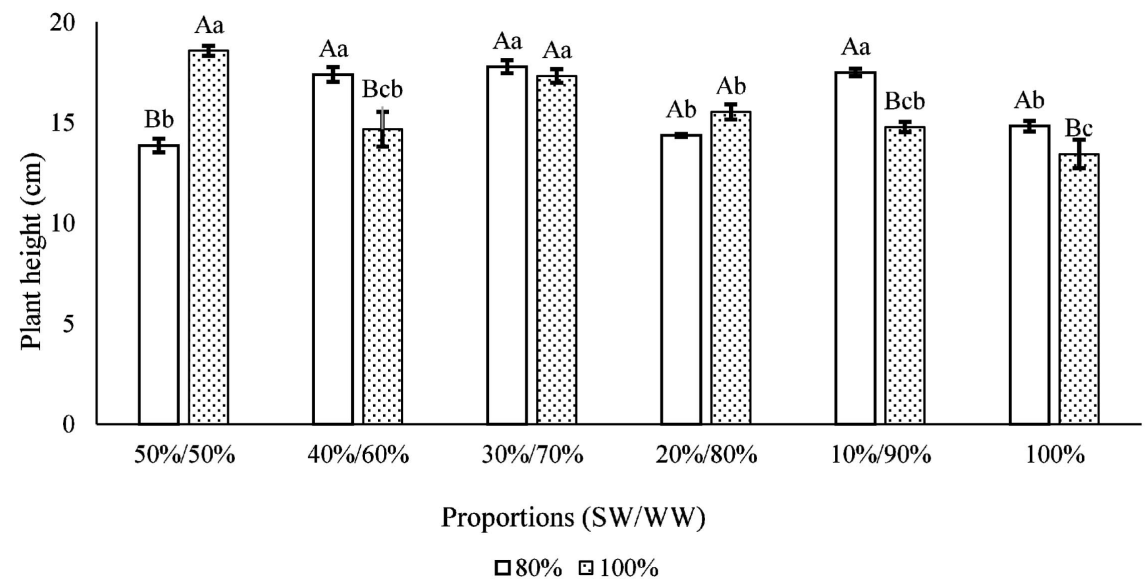

Means followed by different lowercase letters differ for the SW/WW ratios for the Tukey test at 5\% probability and means followed by different capital letters differ from each other for the nutrient solution concentrations for the $t$ test "Student at $5 \%$ probability".

Figure 1. Split of the interaction between the factors for plant height at 55 and 96 DAS.

Table 1. Summary of analysis of variance for plant height (PH), stem diameter (SD), leaf number (LN) and leaf area (LA) of the pepper at 55 and 96 days after sowing (DAS) as a function of the proportions of wastewater/saline water $(\mathrm{P})$ and nutrient solution concentrations (C).

\begin{tabular}{|c|c|c|c|c|c|c|c|c|}
\hline \multirow{3}{*}{$\begin{array}{c}\text { Source } \\
\text { of variation }\end{array}$} & \multicolumn{8}{|c|}{$P$ values (Anova) } \\
\hline & \multicolumn{2}{|c|}{$\mathrm{PH}(\mathrm{cm})$} & \multicolumn{2}{|c|}{$\mathrm{SD}(\mathrm{mm})$} & \multicolumn{2}{|c|}{$\mathrm{LN}(\mathrm{cm})$} & \multicolumn{2}{|c|}{ LA $\left(\mathrm{cm}^{2}\right)$} \\
\hline & 55 DAS & 96 DAS & 55 DAS & 96 DAS & 55 DAS & 96 DAS & 55 DAS & 96 DAS \\
\hline Prop. (P) & $0.0003^{* *}$ & $0.0001^{\star \star}$ & $0.0667 \mathrm{~ns}$ & $0.0001^{\star *}$ & $0.0624 \mathrm{~ns}$ & $0.0001^{\star *}$ & $0.0001^{\star *}$ & $0.0001^{\star *}$ \\
\hline Conc. (C) & $0.0002^{\star *}$ & $0.3349 \mathrm{~ns}$ & $0.0055^{\star *}$ & $0.0001^{\star *}$ & $0.0954 \mathrm{~ns}$ & $0.0001^{\star *}$ & $0.9551 \mathrm{~ns}$ & $0.0001^{\star *}$ \\
\hline $\mathrm{P} \times \mathrm{C}$ & $0.0003^{\star *}$ & $0.0001^{\star *}$ & $0.0363^{*}$ & $0.0001^{\star *}$ & $0.0304^{\star}$ & $0.0001^{\star *}$ & $0.0001^{\star *}$ & $0.0001^{\star *}$ \\
\hline CV (\%) & 5.25 & 5.89 & 6.89 & 2.69 & 9.23 & 8.27 & 11.68 & 6.59 \\
\hline
\end{tabular}

${ }^{* * *, n s}$ Significant at 0.05 and 0.01 probability levels and not significant by F test, respectively. CV: Coefficient of variation. 
nutrient solution. The proportions of $40 \% / 60 \% ; 10 \% / 90 \%$ and $0 / 100 \%$ of saline and residues waters with $80 \%$ of the nutrient solution did not have a significant effect on plant height. This is likely because the nutrition input corresponding to all treatments at 55 DAS was sufficient and similar for plant growth. Comparing the results regarding the concentration of the nutrient solution, that $100 \%$ with the largest quantities of wastewater probably damaged plant height because an excess of plant nutrients.

At the end of the experiment, at 96 DAS, treatments in relation to plant height followed the same behavior in relation to 55 DAS (Figure 1). It is observed in this figure that the proportion $(10 \% / 90 \%)$ with the concentration of $80 \%$ of the nutrient solution becomes the best option, since the addition of the wastewater was enough to supply the decrease in the nutrient solution. Silva et al. [11] observed positive effects on the initial growth of "yellow gold" melon seedlings as the concentration of wastewater increased.

It is observed that at 55 DAS (Figure 2), the stem diameter varied significantly in proportion $(30 \% / 70 \%)$ and in $(0 \% / 100 \%)$, where the concentration of $100 \%$ of

55 DAS

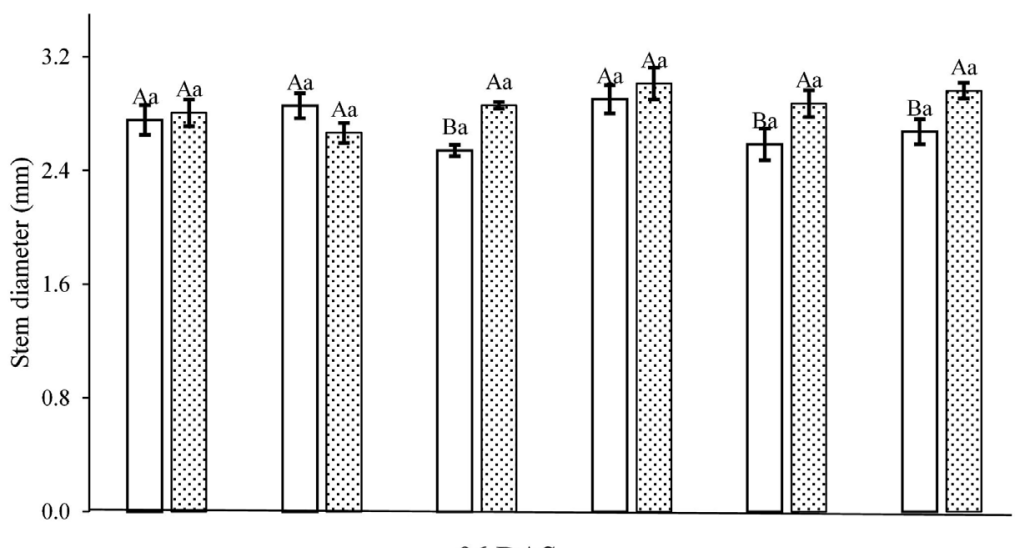

96 DAS

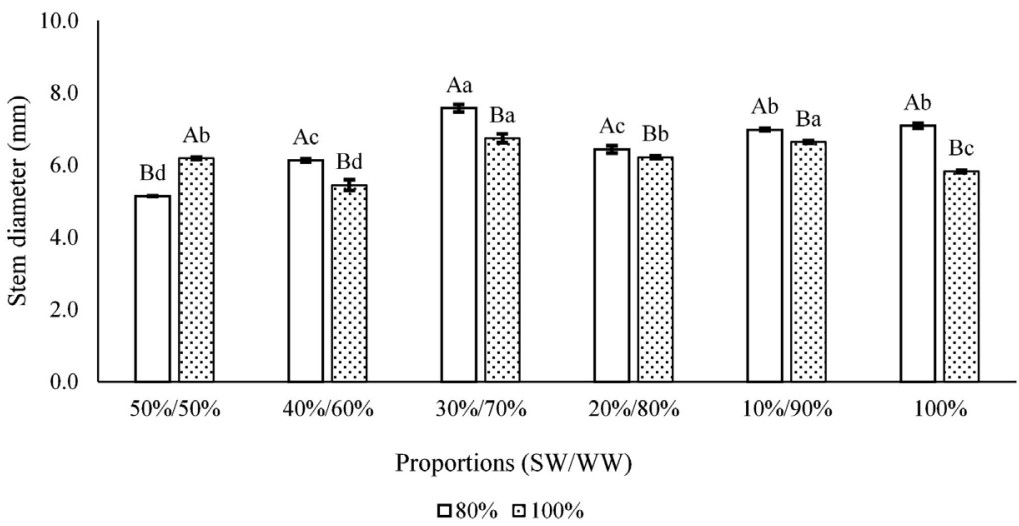

Means followed by different lowercase letters differ for the SW/WW ratios for the Tukey test at 5\% probability and means followed by different capital letters differ from each other for the nutrient solution concentrations for the $t$ test "Student at $5 \%$ probability".

Figure 2. Split of the interaction between the factors for stem diameter at 55 and 96 DAS. 
the nutrient solution had the best behavior. Already at 96 DAS (Figure 2) the best behavior for the stem diameter was observed with the concentrations of $80 \%$ of the nutrient solution, which also was observed at plant height, where the increase of the residual water compensated for the decrease of the nutrient solution. The interaction between these proportions with a concentration of $80 \%$ is probably the best option since it reduces the use with nutrient solution. According to [12] the use of wastewater provided savings in the use of fertilizers in the cultivation of hydroponic lettuce.

The proportions of the waters with $80 \%$ of nutritive solution did not have significant effect on the number of leaves. With the exception of the proportion $20 \% / 80 \%$ with $100 \%$ of the nutrient solution, the other proportions also did not have significant effect on the number of leaves. Likewise, there was practically no significant difference between the concentrations of the nutrient solution in the number of leaves except in the proportions $50 \% / 50 \%$ and $10 \% / 90 \%$ (Figure 3 ).

55 DAS

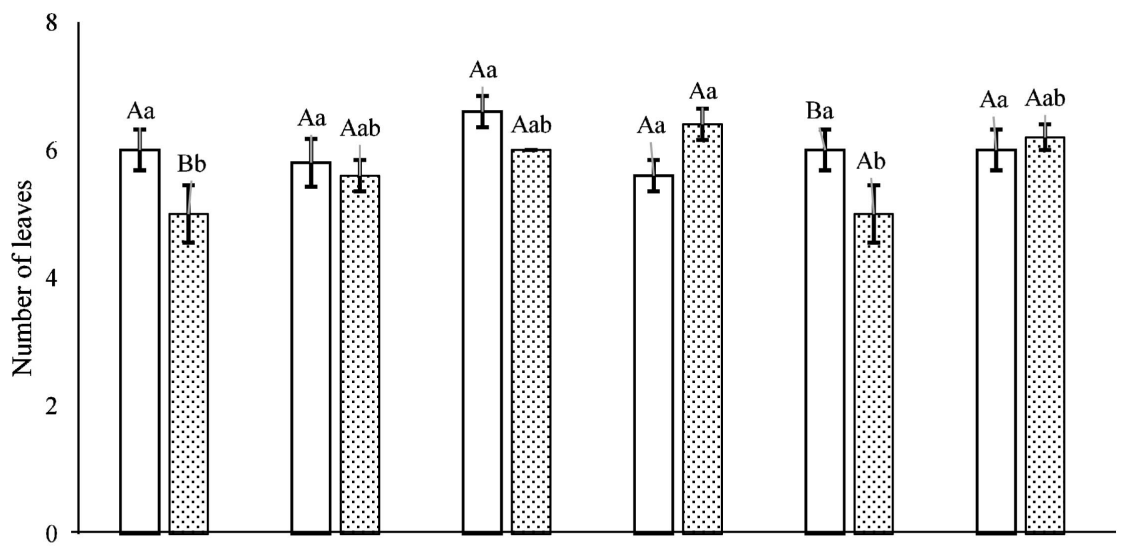

96 DAS

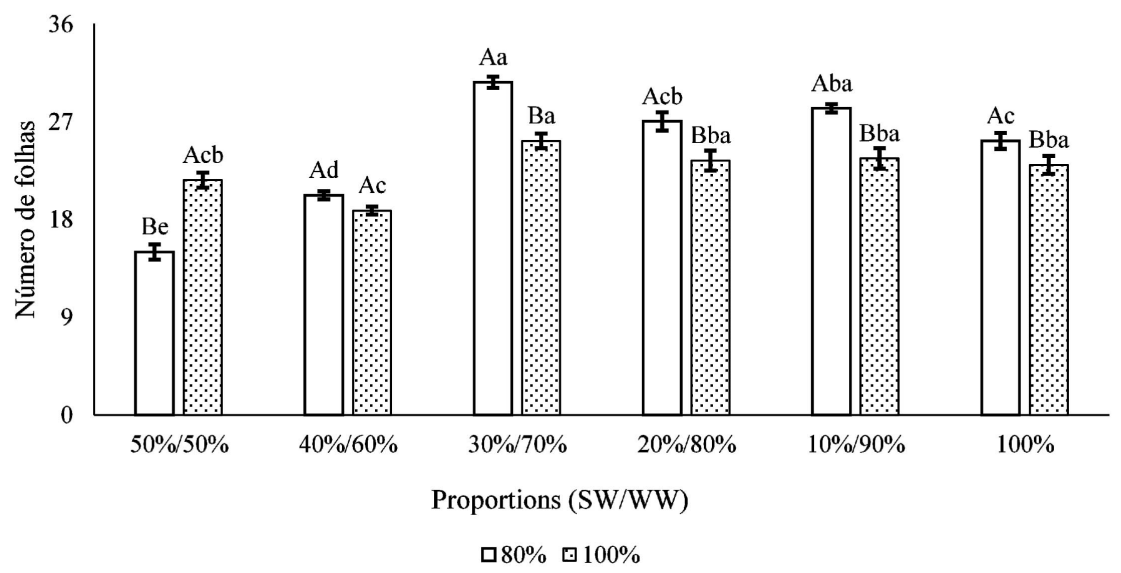

Means followed by different lowercase letters differ for the SW/WW ratios for the Tukey test at 5\% probability and means followed by different capital letters differ from each other for the nutrient solution concentrations for the $\mathrm{t}$ test "Student at $5 \%$ probability".

Figure 3. Split of the interaction between the factors for number of leaves at 55 and 96 DAS. 
However, at 96DAS, plant leaf numbers with $80 \%$ of the nutrient solution were higher than those grown with $100 \%$ of this solution, with the exception of $50 \% / 50 \%$ (Figure 3 ). In this case, the increment of the wastewater was sufficient to overcome the nutritional decrease of $80 \%$ of the nutrient solution. These results are of great importance for hydroponic cultivation, since one of the biggest costs of this system is linked to the nutrient solution.

Cuba [13] studied the cultivation of lettuce in hydroponics observed that it was satisfactory the use of wastewater for this crop, whose results suggested a saving of some fertilizers in relation to the formation of nutrient solution.

At 55 DAS the concentration of $100 \%$ of the nutrient solution had the best behavior in relation to leaf area (Figure 4). However, at 96 DAS was the concentration of $80 \%$ that had the greatest influence on the leaf area of the plants as occurred in other biometric variables (Figure 4 ).

55 DAS

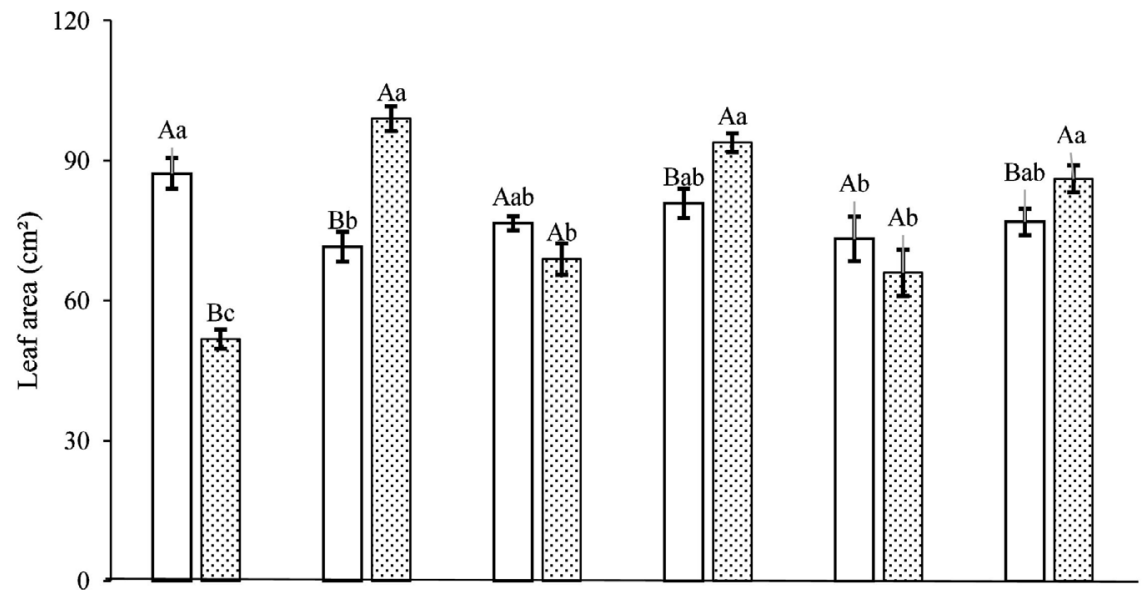

96 DAS

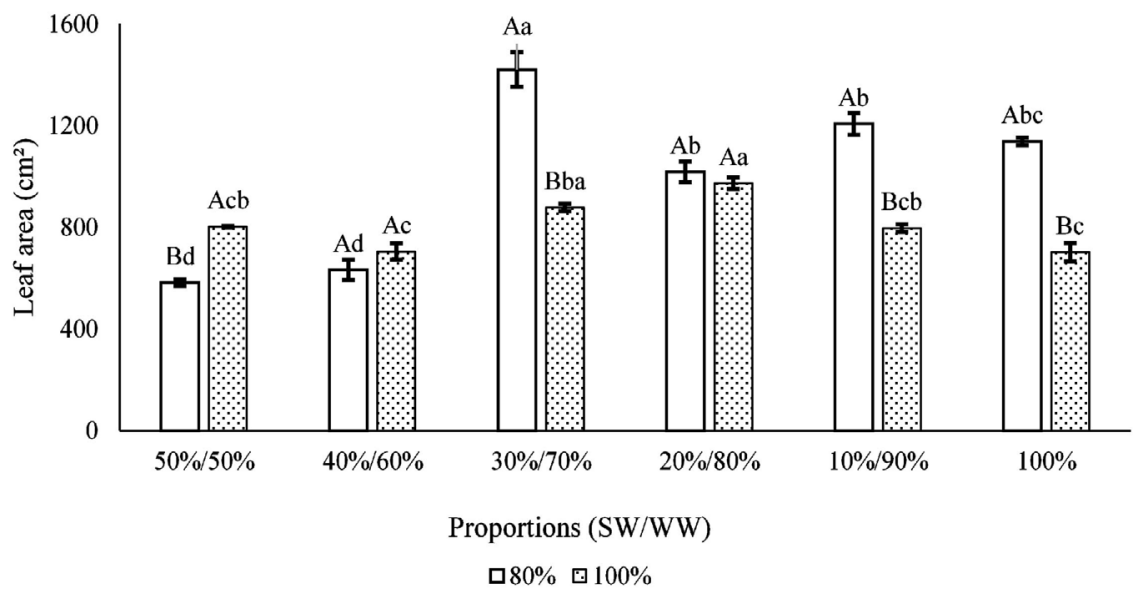

Means followed by different lowercase letters differ for the SW/WW ratios for the Tukey test at 5\% probability and means followed by different capital letters differ from each other for the nutrient solution concentrations for the $t$ test "Student at $5 \%$ probability".

Figure 4. Split of the interaction between the factors for leaf area at 55 and 96 DAS. 
Plant height, leaf diameter, number of leaves and leaf area, at 55 DAS, did not vary greatly according to the treatments, probably because the nutrient supply to the plants was similar with all treatments considering the electrical conductivity of the solutions of these treatments, i.e., 3.88; 3.87; 3.79; 3.56; 3.02 and $2.93 \mathrm{dS} \cdot \mathrm{m}^{-1}$ and $4.42 ; 4.06 ; 4.2 ; 3.66 ; 3.62$ and $3.31 \mathrm{dS} \cdot \mathrm{m}^{-1}$ to the increasing proportions and with concentration of 80 and $100 \%$ of the nutrient solution, respectively. At 96 DAS, the electrical conductivities of the treatments were higher than the initial ones, $4.79 ; 4.63 ; 6.0 ; 4.38 ; 4.56$ and $4.15 \mathrm{dS} \cdot \mathrm{m}^{-1}$ and $5.69 ; 5.4 ; 5.52 ; 4.91 ; 4.88$ and $4.37 \mathrm{dS} \cdot \mathrm{m}^{-1}$, with concentration of $80 \%$ and $100 \%$ of the nutrient solution, respectively, however, they were similar according to the treatments.

In general, it can be observed that for the development of plants cultivated with the smallest quantities of wastewater used in the proportions of the prepared waters, it was necessary to add in these mixtures a nutrient solution with a normal concentration (100\%), thus supplying nutrient deficiency of water. However, the increase of the residual water in the water mixtures was sufficient to overcome the nutritional decrease of $80 \%$ of the nutrient solution. According to [14] owing green pepper, they observed that the fertilizer value of nutrients in wastewater is generally considered beneficial.

Most of the analyzed biometric variables were better influenced with the water prepared with the proportion of $30 \% / 70 \%$ (SW/WW) and $80 \%$ of nutrient solution, however, with the use of water prepared with $10 \% / 90 \%$ (SW/WW) could also be used in hydroponic cultivation, mainly in the semi-arid regions. Due to the scarcity of good quality water in the semi-arid region, it could use larger quantities of wastewater and consequently smaller amounts of nutrient solution, which reduces the costs of using this solution. However, it is interesting to observe that the excess of ions in the solution used in hydroponics generally reduces $\mathrm{CO}_{2}$ assimilation, stomatal conductance, transpiration and photosynthesis of plants [15] [16] and, therefore, end up harming the development of crops.

In the last decades, the use of sewage in agriculture has increased, since it has been revealed as a natural source of fertilizers that guarantee good productivity of irrigated crops. However, reuse of domestic wastewater without any treatment before being used in agriculture, can contaminate the environment by concentrating bacteria, parasites and viruses.

\section{Conclusions}

The interaction between the concentration of the nutrient solution and the ratio of the saline water with wastewater was influenced in the behavior of peppers (cv. All Big) biometric variables.

The nutrient solution prepared at $80 \%$ of its normal concentration had better performance in the development of plants when mixed with the proportions of water containing more wastewater.

The proportion $30 \%$ saline water and $70 \%$ wastewater (30/70) with concentration of $80 \%$ of the nutrient solution obtained better satisfactory results in the 
studied biometric variables.

\section{Conflicts of Interest}

The authors declare no conflicts of interest regarding the publication of this paper.

\section{References}

[1] Sardinha, D.S., Conceição, F.T., Souza, A.D.G., Silveira, A., Julio, M. and Gonçalves, J.C.S.I. (2008) Avaliação da qualidade da água e autodepuração do ribeirão do meio, Leme (SP). Engenharia Sanitária e Ambiental, 13, 329-338. https://doi.org/10.1590/S1413-41522008000300013

[2] Rodrigues, L.R.F. (2002) Técnicas de cultivo hidropônico e de controle ambiental no manejo de pragas, doenças e nutrição vegetal em ambiente protegido. Cultivo pela técnica de hidroponia, Funep, Jaboticabal.

[3] Santos Júnior, J.A., Gheyi, H.R., Cavalcante, A.R., Francilino, A.H. and Perez-Marin, A.M. (2016) Crescimento de girassóis ornamentais sob estresse salino em hidroponia de baixo custo. Irriga, 21, 591-604.

https://doi.org/10.15809/irriga.2016v21n3p591-604

[4] Soares, T.M., Duarte, S.N., Silva, E.F.F. and Jorge, C. (2010) Combinacao de águas doce e salobra para producao de alface hidroponica. Revista Brasileira de Engenharia Agricola e Ambiental, 14, 705-714. https://doi.org/10.1590/S1415-43662010000700004

[5] Almeida, J.P.N., Nunes, R.L.C., Dias, N.S. and Costa, J.M. (2012) Crescimento do pimentão submetido a diferentes níveis de salinidade e fases de exposição. Iinovagri International Meeting \& IV Workshop Internacional de Inovações Tecnológicas na Irrigação, Fortaleza, 29-31 May 2012, 1-5.

[6] Furtado, G.F., Cavalcante, A.R., Chaves, L.H.G., Santos Junior, A. and Ghey, H.R. (2017) Growth and Production of Hydroponic Pepper under Salt Stress and Plant Density. American Journal of Plant Science, 8, 2255-2267.

http://www.scirp.org/journal/ajps https://doi.org/10.4236/ajps.2017.89151

[7] Furlani, P.R., Silveira, L.C.P., Bolonhezi, D. and Faquin, V. (1999) Cultivo hidropônico de plantas. IAC, Campinas, $52 \mathrm{p}$.

[8] Santos Júnior, J.A. (2013) Manejo de águas salinas e residuárias na produção de flores de girassol em sistema hidropônico para regiões semiáridas. UFCG, Campina Grande, $236 \mathrm{p}$.

[9] Swart, E.A.M., Groenwold, R., Kanne, H.J., Stam, P., Marcelis, L.F.M. and Voorrips, R.E. (2004) Non-Destructive Estimation of Leaf Area for Different Plant Ages Andaccessions of Capsicum annuum L. Journal of Horticultural Science \& Biotechnology, 79, 764-770. https://doi.org/10.1080/14620316.2004.11511840

[10] Ferreira, D.F. (2011) Sisvar: A Computer Statistical Analysis System. Ciência e Agrotecnologia, 35, 1039-1042. https://doi.org/10.1590/S1413-70542011000600001

[11] Silva, J.L.D.A., Gurgel, M.T., Mota, A.F., Azevedo, J.D. and Costa, L.R.D. (2012) Influência da água residuária de origem doméstica no crescimento inicial do melão "amarelo ouro". Agropecuária Científica no Semiárido, 8, 16-22.

[12] Júnior, E.A., Azevedo, C.A.V., Azevedo, M.R.Q.A., Xavier, J.F. and Monteiro Filho, A.F. (2016) Qualidade de águas residuárias e salobras utilizadas no cultivo hidropônico 
de três cultivares de alface crespa. Revista Verde de Agroecologia e Desenvolvimento Sustentável, 11, 19-24. https://doi.org/10.18378/rvads.v11i2.4569

[13] Cuba, R.S. (2015) Cultivo hidropônico de alface com água de reuso. UFSCar, São Carlos, 56 p.

[14] Sousa, J.T., Ceballos, B.S.O., Henrique, I.N., Dantas, J.P. and Lima, S.M.S. (2006) Reúso de água residuária na produção de pimentão (Capsicum annuum L.). Revista Brasileira de Engenharia Agrícola e Ambiental, 10, 89-96. https://doi.org/10.1590/S1415-43662006000100014

[15] Silva, S.S., Soares, L.A.A., Lima, G.S., Nobre, R.G., Gheyi, H.R. and Silva, A.O. (2013) Manejo de águas salinas e adubação nitrogenada no cultivo da mamoneira em área do semiárido Paraibano. Agropecuária Científica no Semiárido, 9, 110-117.

[16] Tabagiba, S.D., Moraes, G.A.B.K., Nascimento, K.J.T. and Peloso, A.F. (2014) Limitações fotossintéticas em folhas de plantas de tomateiro submetidas a crescentes concentrações salinas. Engenharia na Agricultura, 22, 138-149.

https://doi.org/10.13083/1414-3984.v22n02a05 